\title{
FERTILIZER REQUIREMENTS OF STEEPLAND SOILS IN THE WANGANUI AND RANGITIKEI DISTRICTS
}

\author{
L. W. BLACKMORE \\ Department of Agriculture, Palmerston N orth \\ T. E. Ludecke and D. E. HogG \\ Ruakura Agricultural Research Centre, Hamilton
}

\section{Summary}

A study of a suite of steepland soils in both the Wanganui and Rangitikei districts showed that the major nutrients limiting the growth of clovers were phosphorus and sulphur. To remedy the phosphate deficiency, $4 \mathrm{cwt}$ of superphosphate per acre was required initially and by applying this amount of superphosphate the sulphur deficiency would also be rectified. Owing to the very low sulphur retention capacities of the soils, the superphosphate should be applied in the spring. The phosphate retention values indicate that the maintenance superphosphate dressings are likely to be $11 / 2$ to 2 cwt per acre annually. The initial responses to lime were small and would not be economic. Molybdenum was not required in the development of these soils.

\section{INTRODUCTION}

THE PRoDuctivity of our grasslands is primarily dependent on high-producing pastures which rely on clovers for their supply of nitrogen. Clovers, in New Zealand, cannot thrive unless adequately supplied with phosphorus, sulphur, potassium and molybdenum. Ineffective nodulation and acid soil conditions may also be factors.

The majority of inland hill country in the Wanganui, Rangitikei, Manawatu and Wairarapa districts is comprised of steepland soils with slopes averaging round 30". The annual rainfall in the Wanganui and Rangitikei districts ranges from 35 in. to 60 in. The soils are classified as steepland soils associated with yellow-grey/yellow-browu earth intergrades and Central yellowbrown earths (Cowie and Campbell, 1965).

A soil suite was selected in the Wanganui and Rangitikei districts where field trials, in which responses to phosphorus, sul- 
phur, lime and molybdenum were measured were laid down, and these were correlated with soil chemical data. It was found possible to determine the type and amounts of fertilizer required for the development of these steepland soils.

By using the soil suite approach in soil fertility investigations, it has been shown that a fertilizer programme can be reliably formulated for legume nutrition for a very large area, with a minimum of field trials (Ludecke, 1962, 1966; Goold and Ludecke, 1969a).

\section{DESCRIPTION OF SOILS}

The soils selected for study in the two geographic areas were a suite of steepland soils derived from sandstone of varying degrees of hardness. Soils derived from sandstones were selected for study because there are considered to be more problems. associated with the agricultural development of -these soils, than with the development of steepland soils derived from mudstones and siltstones.

In the Wanganui district, the soils have been mapped in detail by I. B. Campbell of Soil Bureau, DSIR. Some of the soil properties at the sites selected for study, in order of increasing leaching, are given in Table 1.

The topsoil $\mathrm{pH}$ values and the base saturation in the subsoil decline with increasing leaching as reflected by the precipitation.

An identical suite was selected in the Rangitikei district by J. D. Cowie and I. B. Campbell of Soil Bureau, DSIR. The only difference was that the Upokonui soil at site 4 was replaced by the Pahiatua soil, which has very similar properties. In both dis-

TABLE 1: DETAILS OF WANGANUI SUITE SITES

\begin{tabular}{|c|c|c|c|c|c|}
\hline Site & $\begin{array}{l}\text { Stecpland Soil and } \\
\text { Associated Zonal } \\
\text { G roup }\end{array}$ & Slope & $\begin{array}{l}\text { Estimated } \\
\text { Annual } \\
\text { Rainfall } \\
\text { (in.) }\end{array}$ & $\underset{0-3}{p H} \mathrm{in.}$ & $\begin{array}{c}\text { Base* } \\
\text { turation } \\
(\%)\end{array}$ \\
\hline 1 & Whangaehu YGE/YBE & 32 & $35-40$ & 5.6 & 65 \\
\hline 2 & Taihape YGE/YBE & 32 & $40-42$ & 5.4 & 33 \\
\hline 3 & Mangamahu YBE & $36 "$ & 45 & 5.3 & 25 \\
\hline 4 & Upokonui YBE & $33 ":$ & $50-55$ & 5.1 & 17 \\
\hline
\end{tabular}

*Figures for subsoil samples supplied by I. B. Campbell, Soil Bureau, DSIR, Wanganui. 
TABLE 2: RESULTS OF FIELD TRIALS - MAIN EFFECTS

\begin{tabular}{|c|c|c|c|c|c|c|c|c|c|}
\hline WanGanUI SUITE & CVS & \multicolumn{2}{|c|}{$\begin{array}{l}\text { Phosphorus } \\
\text { Responses }\end{array}$} & \multicolumn{2}{|c|}{$\begin{array}{l}\text { Sulphur } \\
\text { Responses }\end{array}$} & \multicolumn{2}{|c|}{$\begin{array}{c}\text { Lime } \\
\text { Responses }\end{array}$} & \multicolumn{2}{|c|}{$\begin{array}{c}\text { Molybdenum } \\
\text { Responses }\end{array}$} \\
\hline $\begin{array}{l}\text { WaNGANUI SuITE } \\
\text { 1. Whangaehu } \\
\text { 2. Taihape } \\
\text { 3. Mangamahu } \\
\text { 4. Upokonui }\end{array}$ & $\begin{array}{l}10.0 \% \\
\mathbf{1 7 . 1} \% \\
16.0 \% \\
16.9 \%\end{array}$ & $\begin{array}{l}1 \% \\
1 \% \\
1 \% \\
1 \%\end{array}$ & $\begin{array}{r}\text { MR } \\
\text { MR } \\
\text { MR } \\
V M R\end{array}$ & $\begin{array}{l}1 \% \\
1 \% \\
1 \% \\
1 \%\end{array}$ & $\begin{array}{r}\mathrm{R} \\
\mathrm{MR} \\
\mathrm{MR} \\
\mathrm{R}\end{array}$ & $\begin{array}{l}\mathrm{I} \% \\
\mathrm{NS} \\
\mathrm{NS} \\
5 \%\end{array}$ & $\frac{\mathrm{R}}{\mathrm{R}}$ & $\begin{array}{l}\text { NS } \\
\text { NS } \\
\text { NS } \\
\text { NS }\end{array}$ & $=$ \\
\hline $\begin{array}{l}\text { RANGiTiKei Suite } \\
\text { 5. Whangaehu } \\
\text { 6. Taihape } \\
\text { 7. Mangamahu } \\
\text { 8. Pahiatua }\end{array}$ & $\begin{array}{r}13.6 \% \\
8.3 \% \\
26.3 \% \\
22.9 \%\end{array}$ & $\begin{array}{l}1 \% \\
1 \% \\
1 \% \\
1 \%\end{array}$ & $\begin{array}{r}\text { MR } \\
\text { MR } \\
\text { VMR } \\
\text { VMR }\end{array}$ & $\begin{array}{l}1 \% \\
\text { NS* } \\
1 \% \\
1 \%\end{array}$ & $\begin{array}{l}\mathrm{MR} \\
\mathrm{MR} \\
\mathrm{MR}\end{array}$ & $\begin{array}{l}5 \% \\
5 \% \\
1 \% \\
1 \%\end{array}$ & $\begin{array}{r}R \\
R \\
M R \\
M R\end{array}$ & $\begin{array}{l}\text { NS } \\
\text { NS } \\
5 \% \\
\text { NS }\end{array}$ & $\overline{M R}$ \\
\hline $\begin{array}{cc}\text { SILTSTONE } & \text { SoILS } \\
\text { 9. Turakina } & \\
\text { 10. Turakina } & \end{array}$ & $\begin{array}{l}12.7 \% \\
12.2 \%\end{array}$ & $\begin{array}{l}1 \% \\
1 \%\end{array}$ & $\begin{array}{l}\text { MR } \\
\text { MR }\end{array}$ & $\begin{array}{l}1 \% \\
1 \%\end{array}$ & $\begin{array}{l}\text { MR } \\
\text { MR }\end{array}$ & $\begin{array}{l}1 \% \\
5 \%\end{array}$ & $\begin{array}{l}R \\
R\end{array}$ & $\begin{array}{l}\text { NS } \\
\text { NS }\end{array}$ & $=$ \\
\hline
\end{tabular}

Analysis by Duncan's multiple range test. $1 \%$ significant, $5 \%$ significant and NS $=$ non-significant.

$\mathrm{VMR}=$ very marked response, greater than $100 \%$ increase.

MR $=$ marked response 30 to $100 \%$ increase.

$\mathrm{R}=$ response less than $30 \%$ increase.

* Just fails to reach $5 \%$ significance. 
tricts a steepland Turakina soil was included in the study to compare parent materials. The Turakina steepland soils are derived from fine siltstones and rubbly mudstones and are found in areas where the estimated annual rainfall is 45 to 50 in. The Turakina and related siltstone and mudstone soils are considered to be more $\mathrm{f}$ avourable for agricultural development,

The soils at all ten sites were relatively deep (in excess of $24 \mathrm{in}$. and up to $36 \mathrm{in}$.) considering the topography of the trial sites. The soils also showed clear differentiation between the three or four horizons. These profile characteristics would indicate that the soils are relatively mature and are not of recent origin.

\section{FIELD TRIALS}

Locations for the trials were selected which had received little or no previous topdressing, the sites in all cases being on the mid-slopes (i.e., ridges and lower parts of the slopes were avoided). Ten such sites, representing the five soils in both the Wanganui and Rangitikei districts, were oversown with white and subterranean clovers in the late winter and early spring of 1968. Good clover establishment resulted on all sites.

Preliminary soil tests taken before the trials were laid down revealed low levels of both available phosphorus and sulphur; low $\mathrm{pH}$ values in the topsoils at all sites (see Table 1); low to medium calcium levels; and medium to high potash levels.

A factorial design was selected for all ten sites, there being four rates of phosphorus, by two rates of sulphur, by two rates of lime and two rates of molybdenum (i.e., there were 32 plots in each trial). The rates of phosphorus were $0,20,40$ and $80 \mathrm{lb}$ per acre and were applied in the form of calcium monophosphate; these rates are equivalent to $0,2,4$ and $8 \mathrm{cwt}$ per acre of superphosphate. The rates of sulphur, which was applied as elemental sulphur, were 0 and $50 \mathrm{lb}$ per acre; $50 \mathrm{lb}$ of sulphur per acre is equivalent to the sulphur content of $4 \mathrm{cwt}$ of superphosphate. Lime (calcium carbonate) was applied at two rates, 0 and 20 cwt per acre, and molybdenum, in the form of sodium molybdate, at 0 and $5 \mathrm{oz}$ per acre. Basal muriate of potash was applied to all trials at the rate of $1 \mathrm{cwt}$ per acre. Fertilizer treatments were applied in the winter of 1968.

Response patterns were measured visually using the fertility index pointing technique (Lynch and Mountier, 1959). Responses became evident in the late spring of 1968 and were extremely marked by the autumn of 1969 . On most trials the percentage 
of ground covered by white clover in the control plots was $5 \%$, whereas, on the optimum topdressing treatments, the percentage was in the region of 70 .

The main effect responses measured in the autumn of 1969 are shown in Table 2 . The pointings were statistically analysed by Duncan's multiple range test. The levels of statistical significance are given in Table $2(1 \% .5 \%$ and non-significant responses) . To give some indication of the order of the responses, in Table 2, a "very marked response" is a response which was $100 \%$ or more, a marked response was between $30 \%$ and $100 \%$, and a "response" is less than $30 \%$.

The coefficients of variation which are given in Table 2 are extremely low considering the variability of these steepland soils.

Nutrient responses in all ten trials have been very similar. From Table 2 it is evident that the major nutrient factors limiting the growth of clover in these steepland soils are phosphorus and sulphur.

At all ten sites there was a highly significant response $(1 \%)$ to phosphate. The detailed statistical results showed that the opimum rate of phosphorus for maximum clover growth was $40 \mathrm{lb}$ per acre, which is equivalent to the phosphorus content of $4 \mathrm{cwt}$ of superphosphate per acre.

Marked responses (1\% significant) to sulphur were obtained in nine out of ten trials, responses in the trial at site 6 just failing to reach significance.

There were significant interactions between phosphorus and sulphur at eight out of the ten sites. Consequently both these nutrients are essential in the development of these soils.

Responses to lime were obtained in eight of the ten. trials and four of these were significant at the $1 \%$ level. However, in this series of trials, lime responses were small when compared with those from phosphorus and sulphur.

Only one soil responded to molybdenum (site 7) and this was only at the 5\% level of significance. The Mangamahu soil at site 7 has a very sandy texture. Molybdenum is considered to be of negligible importance in the development of these steepland soils.

\section{SOIL Chemistry StUdes}

Soil samples were collected from the surrounds of each of the ten trials in the autumn of 1969. The depths of sampling were 0 to 3 in., 3 to 6 in., 6 to 12 in., 12 to 18 in. and 18 to 24 in. 
TABLE 3: PHOSPHATE AND SULPHUR RETENTIONS MANGAMAHU SITES

\begin{tabular}{|c|c|c|c|}
\hline Site & Depth (in.) & $\begin{array}{c}\text { Phosphate } \\
\text { Retention (\%) }\end{array}$ & $\begin{array}{c}\text { Sulphur } \\
\text { Retention (\%) }\end{array}$ \\
\hline 3 & $\begin{array}{r}\text { o- } 3 \\
3-6 \\
6-12 \\
12-18 \\
18-24\end{array}$ & $\begin{array}{l}13 \\
12 \\
12 \\
22 \\
43\end{array}$ & $\begin{array}{r}-6 \\
-4 \\
0 \\
-4 \\
-8\end{array}$ \\
\hline 7 & $\begin{array}{r}0-3 \\
3-6 \\
6-12 \\
12-18 \\
.18-24\end{array}$ & $\begin{array}{l}21 \\
22 \\
23 \\
27 \\
31\end{array}$ & $\begin{array}{r}-11 \\
-3 \\
1 \\
7 \\
13\end{array}$ \\
\hline
\end{tabular}

Phosphate retention values were determined- according to the method of Saunders (1965) and sulphur retentions by the method described by During and Martin (1968). These analyses were carried out on all samples. As an indication of the values, the results of the analyses from the Mangamahu soils at sites 3 and 7 are given in Table 3.

The phosphate retentions in the 0 to 3 in. and 3 to 6 in. depths at all sites were according to Saunders (1969) mainly in the low range with two soils in the medium range (range 12 to $36 \%$ ). These values, for these steepland soils associated with Central yellow-brown earths, are in agreement with those previously reported by Saunders (1965).

Sulphur retention values for 0 to 3 in. and 3 to 6 in. fall into the range of non-retentive to slightly retentive. From Table 3 it can be seen that sulphur retention values are very low right throughout the profile (similar situation in all other soils). These soils would not .be expected to retain sulphate ions, especially in the high annual rainfalls experienced in these localities.

\section{DISCUSSION}

The marked responses which have been obtained to sulphur in this study are of considerable interest, and are the first recorded on steepland soils derived from sedimentary rocks in the southern half of the North Island. Recently Goold and Ludecke $(1969 \mathrm{~b})^{\circ}$ have shown sulphur to be an essential nutrient in the development of 'a suite of soils derived from massive sandstone in 'Northland. 
There were only two rates of sulphur in these experiments $(0$ and $50 \mathrm{lb}$ ) but, as already stated, the sulphur content of $4 \mathrm{cwt}$ of superphosphate is equivalent to $50 \mathrm{lb}$ of sulphur per acre. By applying $4 \mathrm{cwt}$ superphosphate to remedy the acute phosphate deficiency, sufficient sulphur would be applied. The responses which have been obtained to sulphur rule out the use of pure phosphatic fertilizers in the development of these soils.

The responses to phosphate in the field trials became more marked as leaching increased through the suite. Walker and Adams (1959) showed the manner in which levels of inorganic phosphate declined with increasing leaching and hence this phosphate response pattern would be expected.

Saunders (1969) considers that these soils, with phosphate retention values in the low to medium range, are likely to require, annual phosphate applications equivalent to $1 \frac{1 / 2}{2}$ to $2 \mathrm{cwt}$ of superphosphate per acre to maintain productive ryegrass-white clover pastures.

Owing to the very low sulphur retention values of these soils, right throughout the profile, time of application of superphosphate is important. On peat soils where sulphur retention values are very low, van der Elst (1968) recommends that superphosphate applications should be applied in the spring to alleviate the leaching of calcium sulphate from the superphosphate, through the profile in the wet winter months. On the low sulphurretentive yellow-brown pumice soils in the North Island, M. R. J. Toxopeus (pers. comm.) recommends either split applications of superphosphate in the spring and autumn or the use of sulphurenriched superphosphate in the spring. During and Martin (1968), working on a non-sulphur-retentive gley podzol near Westport, recommend the use of sulphur-enriched superphosphate. Clearly some experimental work should now be undertaken on these soils comparing elemental sulphur and gypsum and also time of application of sulphur fertilizers.

The responses which have been obtained to lime on these soils are relatively small compared with the responses obtained to phosphorus and sulphur. Responses to lime may increase with time but in the initial development of these soils lime applications are not recommended. It is planned to undertake an investigation studying the effect of lower rates of lime on these soils.

Molybdenum was shown not to be required in the development of these steepland soils. 
The fertility status of the Turakina soils derived from siltstone and that of the Mangamahu soils derived from sandstone were found to be very similar in this study.

\section{CONCLUSION}

This study has shown that, for the development of steepland soils derived from sandstone in the Wanganui and Rangitikei districts, an initial application of $\mathbf{4} \mathrm{cwt}$ of superphosphate per acre plus oversowing of clovers and suitable management will result in a highly productive sward within twelve months. Because of the extremely low sulphur-retention values of the soils, the superphosphate should be applied in the spring months. While maintenance requirements of superphosphate have not yet been determined, the low phosphate-retention values would suggest that $1 \frac{1 / 2}{2}$ to $2 \mathrm{cwt}$ of superphosphate per acre applied annually in the spring will suffice. The fertilizer requirements of these steepland soils are relatively low considering their agricultural potential of 5 ewe equivalents per acre (Tripe, 1965).

\section{ACKNOWLEDGEMENTS}

The authors are indebted to many people for their help and co-operation in this study, especially I. B. Campbell and J. D. Cowie, Soil Bureau, DSIR, Dr W. M. H. Saunders, Ruakura Soil Research Station, and finally W. J. P. Mitchell and other field staff in the N.Z. Department of Agriculture at Wanganui, Palmerston North and Taihape.

\section{REFERENCES}

Cowie, J. D.; Campbell, I. B., 1965: Proc. N.Z. GrassId Ass., 27: 23-37.

During, C.; Martin, D. J., 1968: N.Z. Jl agric. Res., II: 665-76.

Goold, G. J.: Ludecke, T. E., 1969a: N.Z. Jlagric. Res. (in press). 1969b: N.Z. Jl agric. Res. (in press).

Ludecke, T. E., 1962: Proc. N.Z. Grassld Ass., 24: 29.41. 1966: Proc. 10th int. Grassld Congr.: 856-9.

Lynch, P. B.; Mountier, N. S., 1959: Proc. N.Z. G rassld Ass., 21: 99-107. Saunders, W. M. H., 1965: - N.Z. Il agric. Res., 8: 30-57. 1969: N.Z. agric. Sci., 4 (3): 19-23.

Tripe, J. 'N., 1965: Proc. N .Z. G rassld Ass., 27: 38-45.

van der Elst, F. C. H., 1968: Proc. 9th int. Soil Congr.: 407-17.

Walker, T. W.; Adams, A. F. R., 1959: Soil Sci., 87: 1-10. 


\section{DISCUSSION}

Asked how long it was before responses became apparent, Ludecke replied that, in the case of phosphate and sulphur applied in the spring, results showed within two months and had become very marked by autumn. Lime took six to eleven months to show any difference. Both Hockey and Burgess considered that superphosphate and sulphur-fortified superphosphate would bc better applied in the autumn in the Taihape area. This led to a good continuing response, while a spring application resulted in problems of controlling pasture growth. Ludecke thought that much of the fertilizer would be leached out by winter rainfall and that the extra cost of sulphur-fortified superphosphate would need to be considered. Blackmore observed that elemental sulphur, which had to be broken down by bacteria, would probably leach to a lesser extent than gypsum sulphur.

To a suggestion by Gibbs that coastal soils of the Wairarapa would not require sulphur but that inland soils would, Ludecke'replied that he was not convinced that coastal soils necessarily contained sufficient sulphur as soils had no real ability to retain $\mathrm{S}$ ions.

The important point was to illustrate the necessity to supply phosphate and sulphur in developing such areas as had been described. 